Tạp chí Khoa học và Công nghệ biển T10 (2010). Số 2. Tr 31 - 43

\title{
NGHIÊN CÚU ĐẠC ĐIỂM BIẾN ĐộNG MỰC NƯỚC BIỂN TRONG ĐIỀU KIỆN BIẾN ĐỔI KHÍ HẬU HIỆN ĐẠI
}

\author{
NGUYẼ̃N KIM VINH
}

Viện Hải dương học

\begin{abstract}
Tóm tắt: Ở đây đã nêu nhưng đặc điểm chính của biến động mưc nước biển trong điều kiện biến đổi khí hậu hiện đại, thực trạng biến đổi mưc nuớc biển ở một số vùng biển Thế giới. Phân tích vai trò của các quá trình chính tham gia vào biến động mưc nuớc biển. Thưc hiện nghiên cứu cu thể (case study) cho vùng biển Nha Trang (Khánh Hòa). Kết quả tính toán và phân tích chuỗi số liệu mưc nước tùng giờ tại Nha Trang, tù 1976 đến 2008, cho thấy xu thế biến đổi mực nuớc biển với chu kì 5,7 năm. Tù 1976 đến 1992 mưc nuớc trung bình có xu thế giảm và tù 1993 đến 2008 - tăng. Áp dụng phuoong pháp lọc Xo-filter, IOC, để xác định thành phần biến đổi không triều của mực nuơóc biển. Gió mùa có vai trò chủ đạo trong biến đổi không triều của mưc nuớc biển. Kết quả tính toán và nghiên cứu có giá trị khoa học và thưc tiễn nhất định.
\end{abstract}

\section{MỞ ĐẦU}

Trong khoảng một thập niên gần đây tai biến thiên nhiên (thiên tai) nói riêng và biến đổi khí hậu nói chung đã gây rất nhiều chú ý cho không chỉ những nhà khoa học nghiên cứu tự nhiên mà còn cho mọi tầng lớp, mọi cư dân của Trái đất, từ các nhà quản lí tới dân chúng trên khắp Thế giới. Nó tác động lên mọi quá trình xảy ra trên Trái đất, cả tự nhiên và xã hội. Và dĩ nhiên, các quá trình nhiệt động lực học xảy ra trong các biển và Đại dương đều chịu tác động của thiên tai.

Biến động mực nước biển là quá trình động lực được chú ý đo đạc và nghiên cứu trước nhất trong Hải dương học. Tuy nhiên, do sự phức tạp và đa dạng của các quá trình tham gia thành tạo biến động mực nước biển, nên cho đến nay vấn đề nghiên cứu vẫn còn tính cần thiết nhất định. Như chúng ta biết, ngoại lực quan trọng nhất tạo nên biến động mực nước biển đó là lực hấp dẫn của Mặt Trăng và Mặt Trời. Nhưng vai trò của các quá trình tác động thứ cấp, như, các quá trình khí quyển đặc biệt (bão, áp thấp nhiệt đới, gió mùa v.v.), các quá trình địa động lực xảy ra trong vỏ Trái đất (động đất, núi lửa phun v.v.), sự thay đổi cân bằng nước trên bề mặt Trái Đất (do một số quá trình, ví dụ: do sự nóng lên 
của khí quyển), cũng rất quan trọng. Vì vậy, nghiên cứu biến động mực nước biển - Đại dương nói chung vẫn mang tính thời sự và cần thiết.

Ở đây trình bày những nét chung về nghiên cứu biến động mực nước biển trong điều kiện biến đổi khí hậu hiện đại và áp dụng cho vùng biển Nha Trang nói riêng.

\section{VỀ BIẾN ĐộNG MỰC NƯỚC BIỂN}

Mực nước biển - Đại dương đã trải qua nhiều đợt biến động mạnh. Ví dụ, trong thời kì băng hà gần đây nhất (khoảng 18.000 năm trước) mực nước Đại dương đã thấp hơn bây giờ là $120 \mathrm{~m}$. (Lục địa đã nối liền Châu Á và Alaska nên người gốc Á đã di cư sang Bắc Mỹ được). Còn vào thời kì nhiệt độ Trái đất và mực nước Đại dương tăng lên cách nay khoảng 8.000 năm, thì mực nước biển đã cao hơn bây giờ là $6 \mathrm{~m}$. Theo đánh giá từ các dữ liệu vệ tinh thì từ năm 1992 đến nay mực nước biển toàn cầu tăng khoảng 2,8 mm/năm. Từ nhiều nguồn dự liệu mực nước đo ở các trạm, người ta đánh giá mức tăng mực nước biển trong thế kỉ XX là trong khoảng $0,8-3,3 \mathrm{~mm} / \mathrm{năm}$, trung bình là $1,8 \mathrm{~mm} / \mathrm{năm}$. Các đánh giá từ dữ liệu địa chất cho thấy mực nước biển có thể tăng $0,1-0,2 \mathrm{~mm} / \mathrm{năm}$ trong vòng 300 năm trở lại đây.

Theo kết quả đo đạc tại 23 trạm đo mực nước tại điểm có độ ổn định về địa hình thì mực nước biển đã tăng $20 \mathrm{~cm}$ trong thế kỉ XX; mỗi năm tăng 2 mm (Riêng giai đoạn 1993 - 2003, tăng 3,1 mm/năm). Nguyên nhân chủ yếu là do hoạt động của con người, như phát triển công nghiệp, tiêu thụ nhiên liệu hóa thạch (dầu khí, than đá v.v), các hoạt động làm tăng lượng khí Cácbon trong khí quyển. Theo một số dự báo thì sau thế kỉ XXI, mực nước biển có thể tăng thêm $1,3 \mathrm{~m}$ [Nguồn Internet]. Mỗi năm có khoảng $8 \mathrm{~mm}$ nước từ toàn bộ bề mặt Đại dương rơi xuống châu Nam Cực và đảo Greenland dưới dạng tuyết. Nếu không có băng tan thì mỗi năm mặt nước biển sẽ tụt xuống $8 \mathrm{~mm}$. Nếu toàn bộ băng ở Greenland tan, mực nước biển sẽ dâng cao 7,2 m; nếu tan hết băng ở châu Nam Cực thì mực nước biển sẽ dâng cao $61,1 \mathrm{~m}$.

Nói chung là sự gia tăng mực nước biển ở từng nơi có khác nhau. Ví dụ, ở bờ Đại Tây Dương và vũng vịnh nước Mỹ nó có thể đạt $3 \mathrm{~mm} / \mathrm{năm}$. Tuy nhiên, theo số liệu các trạm mực nước của Mỹ thì có chỗ tăng (Ví dụ, Vùng Lousiana), có chỗ lại giảm (Ví dụ, vùng Alaska). Những số liệu đo ở Hà Lan (Netherlands) từ năm 1850 cho thấy độ gia tăng khoảng $1,5 \mathrm{~mm} / \mathrm{năm}$. Còn ở Úc (Australia) là $1 \mathrm{~mm} / \mathrm{năm}$ (Chuỗi số liệu từ 1880). Nghiên cứu về biến động mực nước ở Đài Loan (Taiwan) cho thấy, có vùng tăng có vùng giảm. Ở một số vùng giá trị tăng là từ $0,35 \mathrm{~mm} /$ năm đến $1,92 \mathrm{~cm} / \mathrm{năm}$; giá trị giảm ở các vùng khác có thể là từ $0,31645 \mathrm{~cm} /$ năm đến $3,55 \mathrm{~cm} /$ năm [Chen W.J. and C.T. Kuo, 2000]. Kết quả nghiên cứu biến động mực nước biển trong nửa cuối thế kỉ XX ở Nam Trung Quốc 
cho thấy, mực nước biển tăng: ở vùng bờ Macau-Hong Kong giá trị tăng là 2,2 $\pm 0,2$ $\mathrm{mm} / \mathrm{năm}$, ở vùng bờ Nam Trung Quốc: $2,5 \pm 0,2 \mathrm{~mm} /$ năm và ở vùng bờ Đông Trung Quốc: 1,7 \pm 0,2 mm/năm [Ding X. et al, 2004]. Trong vịnh Thái Lan [Punpuk V. 1981] biến động chu kì ngắn của mực nước biển, phụ thuộc chủ yếu vào các quá trình khí tượng, có chu kì 8 - 12 ngày. Trong vùng biển Indonesia, ở vùng bờ phía Nam mực nước trung bình tăng trong khi ở vùng bờ Bắc thì lại giảm, kết luận rút ra từ phân tích chuỗi số liệu từ 1950 đến 1991 [Yanagi T. and T. Akaki, 1994]. Ở vùng Đông của Nhật Bản và Philippines mực nước trung bình tăng trong khi ở vùng bờ Tây thì lại giảm.

Ở Việt Nam, trong khoảng 50 năm qua, nhiệt độ không khí trung bình năm tăng khoảng $0,7^{\circ} \mathrm{C}$ và mực nước biển đã dâng khoảng $20 \mathrm{~cm}$ [Theo Bộ Tài nguyên Môi trường Việt Nam].

Năm 2001, IPCC (Tổ chức Liên Chính phủ về Biến đổi khí hậu - Intergovernmental Panel on Climate Change)đưa ra dự báo là đến năm 2100 mực nước biển sẽ tăng thêm từ 9 đến $88 \mathrm{~cm}$. Đây sẽ là thảm họa rất lớn. Vì, nhiều thành phố lớn ven biển (Như London, New Orleans) phải chống chọi với nước dâng. Nhiều cư dân trên hành tinh chúng ta sẽ lâm vào cảnh không nhà. Ví dụ, theo một đánh giá, mực nước biển chỉ tăng $20 \mathrm{~cm}$ thì đã có 740.000 người dân Nigeria không có nhà ở.

Mực nước biển biến động rất phức tạp, vì có rất nhiều quá trình tác động lên biến động đó. Ví dụ, có nhiều quá trình thành tạo biến động chu kì ngắn (Từ vài phút đến 18,613 năm) của mực nước biển (bảng 1). Thực tế biến động mực nước ở các vùng khác nhau trên Thế giới cho thấy có nơi tăng, có nơi giảm (bảng 2). Chúng ta có thể chú ý tới biến động mực nước ở các nước Philippines, Indonesia và Nhật Bản, là các nước trong vùng Tây Thái Bình Dương.

Từ nhiều nguồn tài liệu có thể thấy rằng chúng ta đang sống trong thời kì nóng lên tiếp theo của khí hậu. Đó chính là thời kì nóng lên hiện đại, khá mạnh, thể hiện ở rất nhiều nơi trên Trái đất. Quá trình nóng lên này bắt đầu từ nửa sau của thế kỉ XIX và mạnh lên vào đầu thế kỉ XX. Ở Đông Âu, nhiệt độ không khí trung bình giai đoạn 1881 - 1915 tăng lên khoảng vài phần mười độ so với thời kì 1846 - 1880. Ở Saint-Petersburg $(\mathrm{Nga})$, nhiệt độ không khí trung bình giai đoạn $1801-1850$ là $+3,5^{\circ} \mathrm{C}$, còn trong thời kì 1921 - 1936 là $+4,6^{\circ} \mathrm{C}$. Các tháng mùa đông nóng lên nhiều nên biên độ năm của nhiệt độ không khí giảm $1,3^{\circ} \mathrm{C}$. Ở Tây Âu, nhiệt độ trung bình 10 năm trước năm 1920 tăng lên $+2,5^{\circ} \mathrm{C}$ so với cuối thế kỉ XIX. Ở Bắc Băng Dương, quá trình nóng lên rất rõ rệt. Ở vùng Đất Mới, nhiệt độ không khí trung bình giai đoạn 1920 - 1935 lớn hơn trong thời kì $1876-1919$ gần $2^{\circ} \mathrm{C}$. Từ năm 1910 đến hết năm 1940 nhiệt độ không khí trung bình ở băng đảo Greenland tăng hơn $3^{\circ} \mathrm{C}$. Tuy nhiên, vấn đề nóng lên của Trái đất trong thời gian gần đây (Lấy ví dụ là thời kì 
từ 1998 đến nay) có lẽ còn là vấn đề tranh cãi [www.nasa.gov]. Có nhiều quá trình tác động lên trạng thái nhiệt của Trái đất chúng ta. Và tất cả các quá trình này cần phải được tính đến trong nghiên cứu biến đổi khí hậu. Ví dụ, theo một vài kết quả nghiên cứu về vũ trụ gần dây nhất, khoảng cách giữa Trái đất và Mặt Trời ngày càng gia tăng. Nếu điều này là đúng thì có nghĩa là lượng bức xạ Mặt Trời đến Trái đất giảm đi. Mặt khác, dân số thế giới ngày càng tăng, các hoạt động (Đặc biệt là phát triển công nghiệp, như khai thác dầu khí, đánh bắt hải sải v.v.) của con người càng tiến gần hơn về hai cực. Điều này cũng làm tăng nhiệt độ khu vực (local) gần các vùng cực, và cũng có thể thúc đẩy quá trình băng tan, v.v.

Bảng 1: Các quá trình thành tạo biến động chu kì biến đổi ngắn của mực nước biển [Segar, 1997]

\begin{tabular}{|c|c|c|c|}
\hline $\begin{array}{l}\text { Loại quá } \\
\text { trình }\end{array}$ & Loại chu kì & $\begin{array}{l}\text { Kích thước thời gian } \\
\text { (P: chu kì) }\end{array}$ & $\begin{array}{l}\text { Hiệu ứng } \\
\text { cao độ }(\mathbf{m})\end{array}$ \\
\hline \multirow{4}{*}{$\begin{array}{l}\text { Biến đổi } \\
\text { chu kì }\end{array}$} & $\begin{array}{l}\text { Nhật triều và bán nhật triều (thủy triều } \\
\text { thiên văn) }\end{array}$ & $12-24$ giờ $\mathrm{P}$ & $0,2 \div 10+$ \\
\hline & Triều chu kì dài & & \\
\hline & Biến động xoay (Chandler wobble) & 14 tháng & \\
\hline & Node Mặt Trăng (thủy triều thiên văn) & 18,613 năm & \\
\hline \multirow{5}{*}{$\begin{array}{c}\text { Biến động } \\
\text { khí tượng } \\
\text { và Hải } \\
\text { dương }\end{array}$} & Khí áp & Vài giờ tới vài tháng & $-0,7 \div 1,3$ \\
\hline & Gió (nước dâng) & $1 \div 5$ ngày & Tới 5 \\
\hline & Bốc hơi và ngưng tụ & Vài ngày tới vài tuần & \\
\hline & $\begin{array}{l}\text { Hình thái bề mặt Đại dương (biến động } \\
\text { của mật độ và dòng chảy nước biển) }\end{array}$ & Vài ngày tới vài tuần & Tới 1 \\
\hline & El Niño/ENSO & 6 tháng trong $5 \div 10$ năm & Tới 0,6 \\
\hline \multirow{4}{*}{$\begin{array}{l}\text { Biến động } \\
\text { mùa }\end{array}$} & Cân bằng nước mùa trong Đại dương & & \\
\hline & $\begin{array}{c}\text { Biến động mùa của độ dốc mực nước } \\
\text { biển }\end{array}$ & & \\
\hline & Lưu lượng sông/ Lũ lụt & 2 tháng & 1 \\
\hline & $\begin{array}{l}\text { Biến đổi mùa của mật độ nước biển } \\
\text { (nhiệt độ và độ mặn) }\end{array}$ & 6 tháng & 0,2 \\
\hline $\begin{array}{l}\text { Dao động } \\
\text { lắc }\end{array}$ & Dao động lắc (Sóng đứng) & Vài phút tới vài giờ & Tới 2 \\
\hline \multirow[t]{2}{*}{ Động đất } & $\begin{array}{l}\text { Sóng thần (Tạo sóng chu kì dài, có sức } \\
\text { tàn phá lớn) }\end{array}$ & Vài giờ & Tới 10 \\
\hline & Biến động bất ngờ của mặt đất & Vài phút & Tới 10 \\
\hline
\end{tabular}


Bảng 2: Biến động của mực nước biển ở các vùng khác nhau trên Thế giới [Yanagi and Akaki, 1994; Ding et al, 2004; Chen and Kuo, 2000]

\begin{tabular}{|c|c|c|c|c|}
\hline \multirow{2}{*}{ STT } & \multirow{2}{*}{ Vùng biển } & \multirow{2}{*}{$\begin{array}{c}\text { Chuỗi số } \\
\text { liệu }\end{array}$} & \multicolumn{2}{|c|}{ Đặc điểm biến động } \\
\hline & & & Tăng & Giảm \\
\hline 1 & Toàn cầu & Thế kỉ XX & $2 \mathrm{~mm} / \mathrm{năm}$ & \\
\hline 2 & Mỹ & & 3 mm/năm & Vùng Alaska \\
\hline 3 & Hà Lan & Từ 1850 & 1,5 mm/năm & \\
\hline 4 & Úc & Từ 1880 & $1 \mathrm{~mm} /$ năm & \\
\hline 5 & Đài Loan & Từ 1900 & $\begin{array}{c}\text { 0,35 mm/năm - 1,92 } \\
\mathrm{cm} / \text { năm }\end{array}$ & $\begin{array}{c}0,364 \mathrm{~cm} / \text { năm }-3,55 \\
\mathrm{~cm} / \text { năm }\end{array}$ \\
\hline 6 & Trung Quốc & $1950-2000$ & 1,7 - 2,5mm/năm & \\
\hline 7 & Indonesia & $1950-1991$ & Vùng Nam & Vùng Bắc \\
\hline 8 & Philippines & $1950-1991$ & Vùng Đông & Vùng Tây \\
\hline 9 & Malaysia & & 2,5 - 8,8 mm/năm & \\
\hline 10 & Nhật Bản & $1950-1991$ & Vùng Đông & Vùng Tây \\
\hline 11 & Pakistan & 50 năm & $0,1 \mathrm{~mm} / \mathrm{năm}$ & \\
\hline 12 & Việt Nam & $1954-2008$ & 0,4 mm/năm & \\
\hline
\end{tabular}

Bảng 3: Các quá trình chính tham gia vào cân bằng (balance) nước Đại dương

\begin{tabular}{|c|c|c|}
\hline STT & Các thành phần & $\begin{array}{c}\text { Vai trò trong } \\
\text { balance nước }\end{array}$ \\
\hline 1 & Bốc hơi & - \\
\hline 2 & Ngưng tụ & + \\
\hline 3 & Băng tan & + \\
\hline 4 & Đóng băng & \pm \\
\hline 5 & $\begin{array}{c}\text { Trao đổi nước giữa Đại dương và Lục địa (Lưu lượng sông } \\
\text { ngòi và nước ngầm) }\end{array}$ \\
\hline 6 & $\begin{array}{c}\text { Hoạt động của con người (Khai thác dầu khí, sản xuất, tiêu } \\
\text { thụ, trữ v.v) }\end{array}$ & - \\
\hline
\end{tabular}


Để xác định được quá trình nào làm thay đổi mực nước biển cần phải xét các thành phần của cân bằng nước (water balance) biển và Đại dương (gọi chung là Đại dương) (bảng 3). Tổng các thành phần là balance. Nếu balance dương có nghĩa mực nước Đại dương tăng và ngược lại, âm - giảm. Và cũng qua các giá trị thành phần mới có thể nói về vai trò của thành phần nào là chính. Đây rõ ràng là việc không đơn giản.

\section{III. ĐẶC ĐIỂM BIẾN ĐộNG MỰC NƯỚC VÙNG BIỂN NHA TRANG}

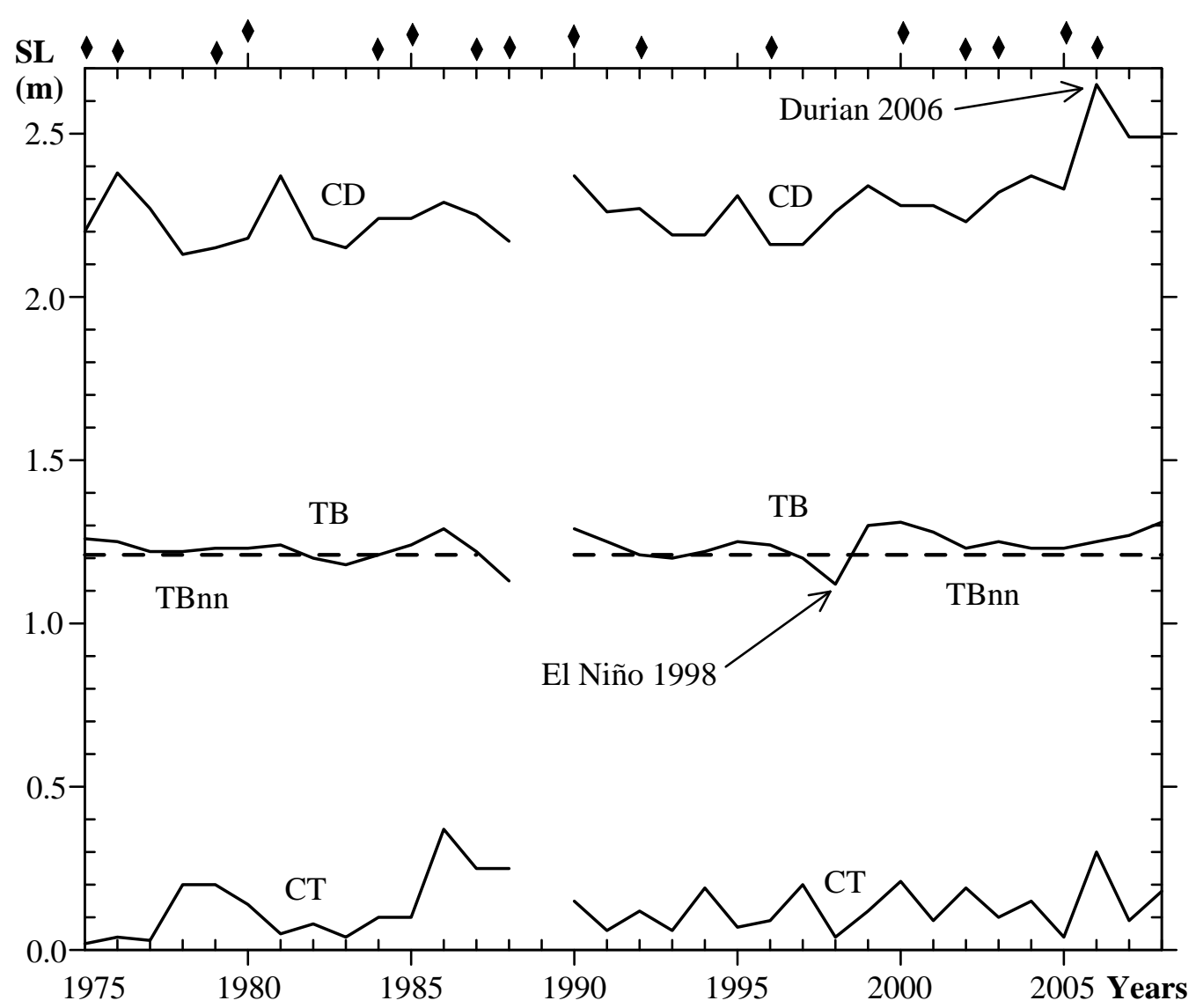

Hình 1: Các đặc trưng thống kê mục nước trạm Cầu Đá (Nha Trang). TB - Giá trị trung bình năm, TBnn - Giá trị trung bình nhiều năm (1975 - 2008), CD - Giá trị cực đại năm,

CT - Giá trị cực tiểu năm, - Chỉ năm không có đầy đủ số liệu mực nước từng giờ

Có thể nói, biến động mực nước biển bao gồm hai thành phần chính: Thành phần biến đổi triều (the tidal variation of sea level) và thành phần biến đổi không triều (the nontidal variation of sea level). Trong phần này trình bày các đặc trưng biến đổi chung và của thành phần biến đổi không triều trong vùng biển Nha Trang (Khánh Hòa). 


\section{Các đặc trưng thống kê mục nước biển trạm Cầu Đá (Nha Trang)}

Bảng 4: Các chu kì triều chính [Douglas A. Segar, 1997]

\begin{tabular}{|c|c|c|}
\hline STT & Chu kì & Ghi chú \\
\hline 1 & $12 \mathrm{~h} 24.5^{\prime}$ & Bán nhật triều \\
2 & $24 \mathrm{~h} 49^{\prime}$ & Nhật triều \\
3 & 6 tháng & Nửa năm \\
4 & 12 tháng & Một năm \\
5 & 14,5 tháng & Triều ở cực \\
6 & 8,47 năm & Triều Perigee \\
7 & 10,8 năm & Chu kì Đốm Mặt Trời (Sunspot cycle) \\
8 & $18,6(18 \div 19)$ năm & Triều giao điểm (Nodal tide) \\
\hline
\end{tabular}

\section{$\mathbf{S L}(\mathbf{m})$}

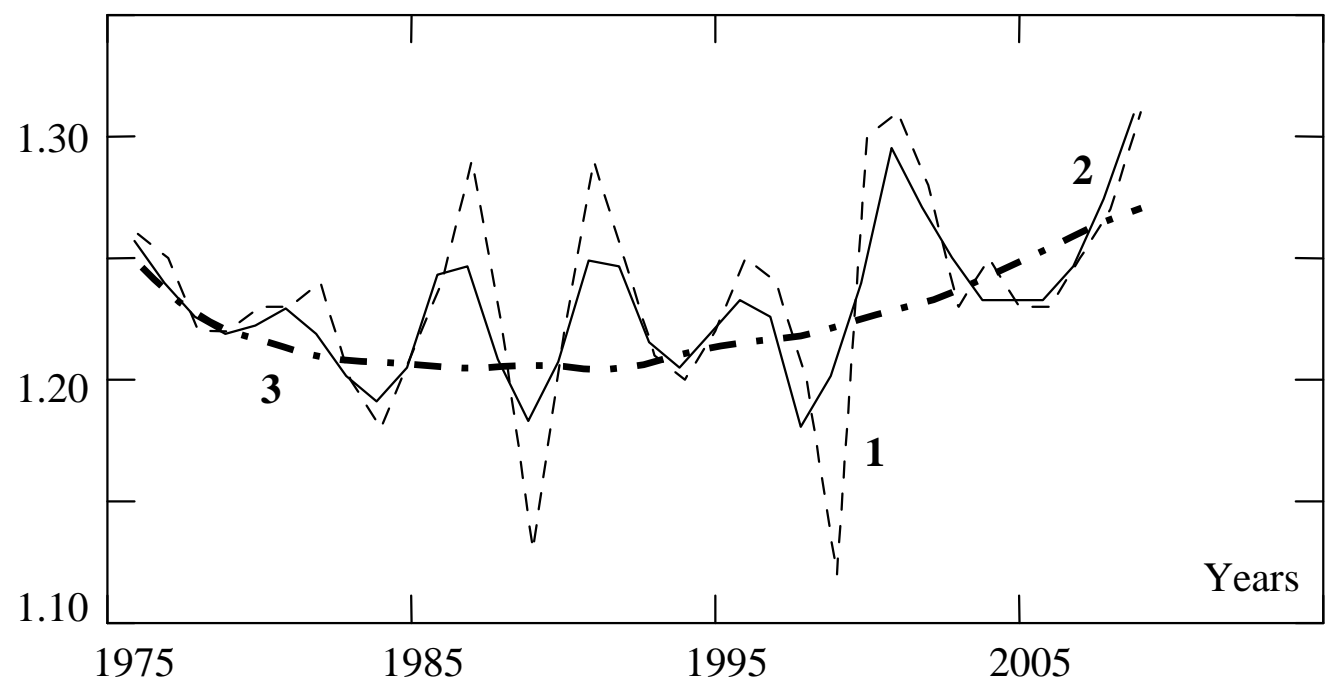

Hình 2: Xu thế biến đổi của giá trị trung bình năm mực nước trạm Cầu Đá, Nha Trang. 1 - Giá trị trung bình năm (đường gạch - gạch), 2 - giá trị là trơn (đường liền), 3 - Xu thế biến đổi (tendency) của giá trị trung bình năm mực nước (đường gạch - chấm)

Các đặc trưng thống kê mục nước trạm Cầu Đá (Nha Trang) được thể hiện trên hình 1. Có sự biến động rõ rệt các giá trị trung bình năm từ năm 1976 đến năm 2008 (Đường 
TB). Tuy nhiên, vì số liệu đo đạc mực nước ở đây chưa đầy đủ, còn nhiều hạn chế về tính liên tục và độ kéo dài, nên những nhận xét nêu ra là những định hướng ban đầu để tham khảo. Trong khoảng một thập niên gần đây, tai biến thiên nhiên (thiên tai) và biến đổi khí hậu đã gây rất nhiều chú ý cho không chỉ những nhà khoa học nghiên cứu tự nhiên mà còn cho mọi tầng lớp, mọi cư dân của Trái đất, từ các nhà quản lí tới dân chúng trên khắp Thế giới. Nó tác động lên mọi quá trình xảy ra trên Trái đất, cả tự nhiên và xã hội. Và dĩ nhiên, các quá trình nhiệt động lực học xảy ra trong các biển và Đại dương đều chịu tác động của thiên tai. Biến động mực nước biển là quá trình động lực được chú ý đo đạc và nghiên cứu trước nhất trong Hải dương học, cũng vậy. Nhưng từ chuỗi số liệu mực nước biển trạm Cầu Đá (Nha Trang) hiện có (Thể hiện qua các đặc trưng thống kê trên hình 1) không có thể đưa ra nhận định về sự gia tăng mực nước biển trong vùng biển Nha Trang.

Như ta biết, biến động triều có 8 chu kì chính, từ 12h24.5' đến 18,6 năm (bảng 4). Rõ ràng là với chuỗi số liệu hiện có của trạm Mực nước biển Cầu Đá, Nha Trang, không thể nêu nhận xét về sự gia tăng của mực nước biển do biến đổi khí hậu (hiệu ứng nhà kính, sự nóng lên của Trái đất) nói chung và băng ở các cực Trái đất tan ra, nói riêng. Để củng cố thêm nhận định này chúng ta có thể áp dụng hai phương pháp sau: 1- Là chuỗi số liệu, 2 - Là đồ thị. Sử dụng các phần mềm thông dụng, ta sẽ có kết quả của hai phương pháp vừa nêu (hình 2). Có thể thấy rằng, trong vòng 34 năm giá trị trung bình năm của mực nước trạm Cầu Đá biến đổi với khoảng 6 chu kì (đường 2, hình 2), nghĩa là 1 chu kì khoảng 5,7 năm. Còn xu thế biến đổi chung là: Từ 1975 đến 1992: giá trị trung bình năm của mực nước giảm, từ 1992 đến 2008: tăng (đường 3, hình 2). Chênh lệch giá trị trung bình năm của mực nước năm 2008 và 1975 là 5 cm.

Phân tích kĩ kết quả tính toán thu được ta có thể đưa ra một vài nhận xét khá lí thú. Thứ nhất đó là, tồn tại một giá trị cực tiểu trung bình năm 1998 (Rất rõ rệt, hình 1). Năm 1998 là năm có hiện tượng El Niño rất mạnh (Có thể xem nhiều nguồn tài liệu trên Internet). Điều này làm ta liên tưởng đến khả năng ảnh hưởng của El Niño và La Niña (ENSO) đến biến đổi mực nước biển trong Biển Đông. Đỉnh cực đại mực nước tồn tại ở năm 2006 làm ta liên hệ tới ảnh hưởng của bão lên biến động mực nước biển trong vùng. Mà cụ thể là bão Durian [http://www.nchmf.gov.vn].

Vào tháng 7 (mùa gió mùa Tây Nam) giá trị trung bình tháng của mực nước biển thấp hơn vào tháng 12 (mùa gió mùa Đông Bắc), trung bình là $28 \mathrm{~cm}$ (hình 3 ). So với trung bình nhiều năm, mức chênh lệch mực nước trong các mùa gió mùa (lấy ví dụ là tháng 7 và 12) là $14 \mathrm{~cm}$. 


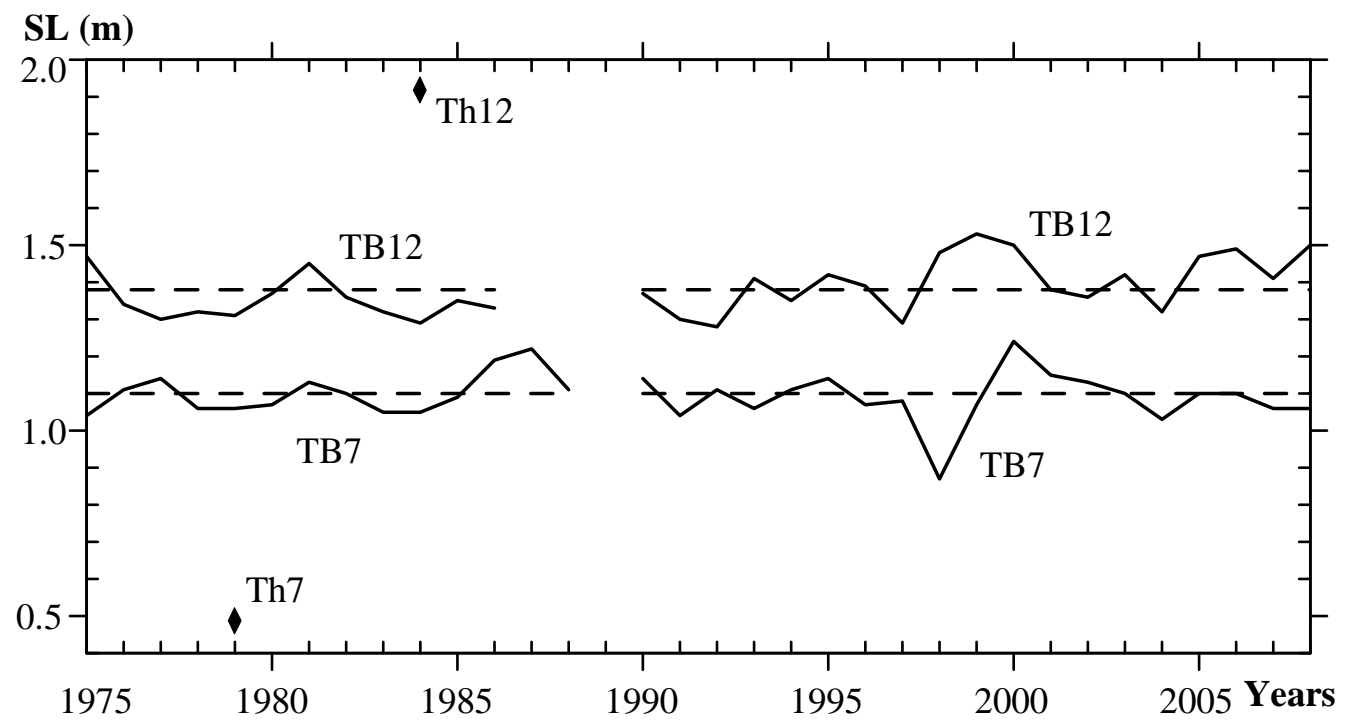

Hình 3: Trung bình mực nước tháng 7 (TB7) và tháng 12 (TB12) các năm 1975 - 2008, trạm Cầu Đá (Nha Trang). - Chỉ tháng không có đầy đủ số liệu mực nước từng giờ

\section{Nghiên cứu biến động không triều}

Biến động không triều của mực nước biển do một số quá trình xảy ra trong khí quyển, Đại dương và vỏ Trái đất tạo thành. Vì vậy, cần có khái niệm rõ ràng về các quá trình này.

\section{Các quá trình xảy ra trong khí quyển:}

a- Trước hết phải kể đến các hiện tượng thời tiết đặc biệt, như bão (gọi chung là xoáy thuận nhiệt đớii: XTNĐ), áp thấp nhiệt đới (ATNĐ - tropical depression) và lũ lụt vùng bờ.

b- Trường khí áp (áp suất khí quyển) cũng luôn luôn biến động. Vì vậy nó cũng tác động lên mực nước biển và làm cho mực nước biển biến động. Đặc biệt phải kể đến quá trình ENSO. Cá biệt trong vùng nhiệt đới, khí áp biến động với chu kỳ bán nhật triều nên ở vùng biển nước ta cũng vậy [Nguyễn Kim Vinh, 1992].

c- Tác động của trường gió gần bờ có thể gây nên hiện tượng nước dâng - rút Ở vùng biển ven bờ Việt $\mathrm{Nam}$, hiện tượng này có thể được gây nên bởi gió mùa và gió đất biển (breeze) [Nguyễn Kim Vinh, 1992, 1997; Đặng Văn Hoan, Nguyễn Kim Vinh, 1998]. Ở vùng Nam Trung bộ và Nam bộ có gió chướng.

d- Hiệu ứng nhà kính (greenhouse effect) và hậu quả là sự gia tăng nhiệt độ khí quyển nói chung làm tan chảy băng ở các cực Trái đất cũng làm tăng mực nước biển. 


\section{Các quá trình xảy ra trong Đại duơng (Có tài liệu gọi là Thủy quyển):}

e- Hoàn lưu nước biển Đại dương trong sự tác động của lực Koriolis có thể gây nên biến động mực nước biển; đặc biệt là ở vùng bờ, vùng có các xoáy (eddy, gyre, meander). Tuy nhiên, giá trị biến động mực nước biển trong trường hợp này nhỏ hơn nhiều so với các trường hợp khác (ví dụ, bão).

f- Quá trình truyền triều ở các vùng cửa sông trong trường hợp có lượng nước sông tương đối chảy ra thường gây nên sự gia tăng đáng kể của mực nước trong vùng. Đối với vùng biển Việt $\mathrm{Nam}$, hiện tượng này thường thấy ở vùng đồng bằng Nam bộ nói chung, thành phố Hồ Chí Minh nói riêng; gây trở ngại lớn cho đời sống của nhân dân trong vùng. Người dân địa phương và báo chí thường gọi là "triều cường", vì nó thường xảy ra vào thời kì triều cường.

\section{Các quá trình xảy ra trong vỏ Trái đất:}

g- Các quá trình xảy ra trong vỏ Trái đất, như động đất (earthquake), núi lửa (volcano), nhất là khi chúng xảy ra dưới đáy biển, Đại dương, có thể tạo nên những biến động bất thường của mực nước biển (tsunami).

h- Các quá trình thủy thạch động lực xảy ra trong vùng bờ biển và các đảo cũng có thể làm biến động mực nước biển trong vùng.

Như vậy, ở trên đã tổng quan 8 quá trình xảy ra trong khí quyển, Đại dương và vỏ Trái đất có khả năng tham gia vào biến động không triều của mực nước biển. Ở đây không tính đến biến động mực nước biển với chu kỳ ngắn; cụ thể là sóng biển do gió tạo thành.

\subsection{Phương pháp tính thành phần không triều}

Đối với biến động mực nước biển, để loại bỏ các quá trình biến đổi triều, cần áp dụng phép lọc có tên là Xo-filter [Manual on sea level measurement and interpretation, IOC, 1985]. Phép lọc này được xác định như sau:

$$
F(t)=(2,1,1,2,0,1,1,0,2,0,1,1,0,1,0,0,1,0,1)
$$

với $t: 1 \div 19$. Đây là bộ lọc đối xứng, nghĩa là $F(t)=F(-t)$. Và để loại bỏ các biến động triều cần tính theo công thức sau:

$$
X_{T}=\frac{1}{30} \sum_{d=-19}^{d=19} F(d) H(T+d), \quad \quad \text { với } d \neq 0
$$

Trong đó, $H(t)$ là mực nước từng giờ. Phương pháp được áp dụng cho $T=12$ giờ. 


\subsection{Kết quả}

Để nghiên cứu biến động không triều của mực nước biển đã sử dụng dãy số liệu từng giờ của Trạm Mực nước biển Cầu Đá (Phòng Vật lí biển, Viện Hải dương học). Áp dụng phương pháp lọc (Mục III.2.1.) ta thu được chuỗi giá trị mực nước biển không triều. Từ đó có thể nêu các đặc trưng và đặc điểm biến động không triều của mực nước biển. Giá trị biến đổi không triều trong năm dao động trong khoảng $52 \mathrm{~cm}$ đến $108 \mathrm{~cm}$. Như vậy, giá trị biến đổi không triều cực đại bằng $46 \%$ biến đổi mực nước lớn nhất (Biến đổi mực nước lớn nhất là $238 \mathrm{~cm}$, vào tháng 11 ). Rõ ràng, vai trò của biến đổi không triều trong quá trình biến đổi chung của mực nước biển trong vùng là rất đáng kể.

Bảng 5: Biến động không triều của mực nước biển $(\Delta \mathrm{H}, \mathrm{cm})$, và gió $(\mathrm{W}$ : hướng gió chính và tốc độ trung bình, $\mathrm{m} / \mathrm{s}$ ) vào ngày 15 hàng tháng năm 1983

\begin{tabular}{|c|c|c|c|c|c|c|c|c|c|c|c|c|}
\hline Tháng & $\mathbf{1}$ & $\mathbf{2}$ & $\mathbf{3}$ & $\mathbf{4}$ & $\mathbf{5}$ & $\mathbf{6}$ & $\mathbf{7}$ & $\mathbf{8}$ & $\mathbf{9}$ & $\mathbf{1 0}$ & $\mathbf{1 1}$ & $\mathbf{1 2}$ \\
\hline$\Delta \mathrm{H}$ & 9 & 8 & 0 & -18 & -21 & -12 & 1 & 11 & -9 & 15 & 17 & 10 \\
\hline \multirow{2}{*}{$\mathrm{W}$} & $\mathrm{WNW}$ & $\mathrm{WNW}$ & $\mathrm{SE}$ & $\mathrm{SE}$ & $\mathrm{SE}$ & $\mathrm{SE}$ & $\mathrm{SE}$ & $\mathrm{ESE}$ & $\mathrm{SE}$ & $\mathrm{NE}$ & $\mathrm{NW}$ & $\mathrm{NE}$ \\
& 5.5 & 2.0 & 2.0 & 2.0 & 2.5 & 4.0 & 1.5 & 1.5 & 1.2 & 1.5 & 3.0 & 3.5 \\
\hline
\end{tabular}

Để xét ảnh hưởng của gió mùa lên biến động không triều của mực nước biển trong vùng, đã chọn hai tháng: 1 - đại diện cho mùa gió Đông - Bắc và 2 - đại diện cho mùa gió Tây - Nam. Giá trị trung bình năm biến động không triều trong hai tháng này là: Vào tháng 1: từ 1 đến $14 \mathrm{~cm}$, vào tháng 7 : từ -6 đến $-26 \mathrm{~cm}$. Giá cực đại năm biến động không triều trong hai tháng này là: Vào tháng 1 : từ 9 đến $24 \mathrm{~cm}$, vào tháng 7 : từ -15 đến -35 cm.Ở đây, giá trị dương có nghĩa là gió mùa Đông - Bắc làm gia tăng mực nước biển, còn giá trị âm: gió mùa Tây - Nam làm giảm mực nước biển. Trong đó, gió mùa Tây - Nam gây biến động mực nước biển mạnh hơn, về giá trị khoảng gấp 2 lần.

Để nghiên cứu nguyên nhân chính tạo nên thành phần biến động không triều của mực nước biển trong vùng, có thể xét mối tương quan giữa gió (tốc độ và hướng) và giá trị thành phần biến động không triều (bảng 5). Kết quả tính toán biểu thức liên hệ giữa mực nước không triều và tốc độ gió trên cơ sở dữ liệu năm 1983 cho thấy mối tương quan cao (biểu thức 3):

$$
\mathrm{h}=1,382 \mathrm{~W}+13,3
$$

Trong đó, $[\mathrm{W}]: \mathrm{m} / \mathrm{s},[\mathrm{h}]$ : $\mathrm{cm}$. Với sai số tương đối trung bình là $2.5 \%$. Giá trị sai số tương đối trung bình này rất nhỏ (chỉ đạt 2.5\%), chứng tỏ trong năm 1983 thành phần biến động không triều chủ yếu là do gió tạo thành. 


\section{KẾT LUẬn}

Quá trình biến động mực nước biển trong điều kiện biến đổi khí hậu hiện đại ngày càng phức tạp; đòi hỏi phải tiến hành những đo đạc nghiên cứu toàn diện các quá trình thành tạo biến động đó.

Kết quả tính toán và phân tích chuỗi số liệu mực nước từng giờ tại Nha Trang, từ 1976 đến 2008, cho thấy xu thế biến đổi mực nước biển với chu kì 5,7 năm. Từ 1976 đến 1992 mực nước (theo xu thế) giảm và từ 1993 đến 2008 - tăng.

Kết quả nghiên cứu biến động không triều của mực nước biển ở vùng vịnh Nha Trang đã cho kết quả tốt, có cả giá trị khoa học và thực tiễn. Vì vậy, có thể áp dụng cho các vùng biển khác của Việt Nam.

Lời cảm ơn: Tác giả chân thành cám ơn cố PGS. TS. Võ Văn Lành và TS. Bùi Hồng Long, giám đốc Monitoring - Đài trạm Viện Hải dương học, các nhà khoa học của Phòng Vật lí biển Viện Hải dương học (TS. Nguyễn Bá Xuân, TS. Lã Văn Bài, TS. Lê Đình Mầu, CN. Vũ Tuấn Anh, ThS. Phạm Xuân Dương, ThS. Trần Văn Chung, ThS. Nguyễn Văn Tuân, ThS. Phạm Sỹ Hoàn, CN. Nguyễn Chí Công), đã hỗ trợ và giúp đỡ để tác giả có thể thực hiện được nghiên cứu này.

\section{TÀI LIỆU THAM KHẢO}

1. Chen W.J., C.T. Kuo., 2000. Sea level variation around Taiwan. Conference Proceeding, Seoul, (Nguồn Internet).

2. Đặng Văn Hoan, Nguyễn Kim Vinh, 1998. Biến đổi của mực nước biển ở vịnh Nha trang. Tuyển tập nghiên cứu biển, VIII, 13 - 19. Nxb Khoa học và Kỹ thuật. Nha Trang.

3. Ding X., D. Zheng, W.T. Wong, K.W. Li, W. Chen, P. Zhong, 2004. Recent sea level variations in Southern China from tide gauge observations. Proceedings of the Asia-Pacific Space Geodynamics Symposium, Singapore, 126-136.

4. Douglas A. Segar, 1997. Introduction to Ocean Sciences. Wadsworth Publishing Company. 497 pp.

5. Manual on sea level measurement and interpretation, IOC, 1985. $83 \mathrm{pp}$.

6. Yanagi T., T. Akaki, 1994. Sea level variation in the Eastern Asia. J. of Oceanography, Vol. 50, 643-651. 


\title{
STUDY OF THE VARIATION CHARACTERISTICS OF SEA LEVEL IN THE CONDITION OF PRESENT CLIMATE CHANGE
}

\author{
NGUYEN KIM VINH
}

Summary: The main characteristics of sea level variation in the condition of present climate change and the real situation of sea level variation in different marine areas are noted. The roles of the main processes participating in variation of the sea level are analyzed. The case study is applied to Nha Trang Bay (Khanh Hoa province). The analysis of the series of hourly sea level data from 1976 to 2008 showed that the sea level changes with the period of 5.7 years. The tendency of the average sea level is that from 1976 to 1992 decreased and from 1993 to 2008 increased. The Xo-filter (IOC, 1985) is applied to define the non-tidal component of the sea level variation. The monsoon plays the main role in forming of the nontidal component of sea level variation in this area. It is noted that the results of calculation and research have accepted scientific and practice values.

Ngày nhận bài: 24 - 10 - 2009

Ngườ nhận xét: $\quad$ PGS. TS. Đỗ Ngọc Quỳnh

TS. Lê Đình Màu 